\title{
APLIKASI ABSENSI SISWA BERBASISKAN ANDROID
}

\author{
Sherly Christina ${ }^{1)}$, Enny Dwi Oktaviyani' ${ }^{2)}$, Deddy Ronaldo ${ }^{3)}$, Rosya M. Zaini ${ }^{3)}$ \\ ${ }_{1,2,3,4)}$ Teknik Informatika, Universitas Palangka Raya \\ e-mail: sherly.christina.upr@gmail.com ${ }^{1)}$,enny.obrien@gmail.com²), \\ deddy.ronaldo@gmail.com ${ }^{3)}$,rosyaocha1113@gmail.com ${ }^{3)}$
}

\begin{abstract}
The recording of student attendance aims to monitor the student attendance quantity and educate students to be disciplined. Student attendance records that are currently done manually on the paper can be improved to increase the quality of the attendance data processing, service quality and system in the School. This study aims to build an Attendance application based on Android platform that can be used on the teacher's mobile device. Waterfall is the method which is used to develop the attendance application in this study. Then, to ensure the application performance, the attendance application will be tested by the blackbox testing method. The test results using the blackbox testing show that the features in the attendance application perform according to its purpose. This attendance application can facilitate the homeroom teacher to carry out the student attendance recording process daily and to create the student attendance data recapitulation.
\end{abstract}

Keywords: Android, Application, Student attendance, Waterfall.

\section{ABSTRAK}

Absensi siswa bertujuan untuk memonitor tingkat kehadiran siswa dan mendidik siswa untuk disiplin. Pencatatan absensi siswa yang saat ini dilakukan secara manual di atas kertas dapat diperbaiki, sehingga dapat meningkat mutu pengolahan data presensi, mutu layanan dan sistem di Sekolah. Penelitian ini bertujuan membangun aplikasi Absensi berbasis Android yang dapat digunakan pada perangkat handphone guru. Waterfall adalah metode yang digunakan untuk mengembangkan aplikasi absensi pada penelitian ini. Kemudian untuk memastikan performa aplikasi, aplikasi absensi akan diuji menggunakan metode blackbox testing. Hasil pengujian dengan blackbox testing menunjukkan bahwa fitur-fitur dalam aplikasi Absensi dapat berfungsi sesuai dengan tujuannya. Aplikasi Absensi ini dapat memfasilitasi Guru Wali Kelas melakukan proses absensi siswa sehari-hari dan membuat rekapitulasi data absensi.

Kata Kunci: Absensi siswa, Android, Aplikasi, Waterfall.

\section{PENDAHULUAN}

$\mathrm{B}$ BSENSI adalah sebuah kegiatan pengambilan data guna mengetahui jumlah ketidakhadiran peserta dalam suatu kegiatan. Proses absensi merupakan kegiatan yang dilakukan dalam kegiatan akademik di sekolah untuk mengetahui frekuensi keaktifan siswa di sekolah.

Mengurangi jumlah ketidakhadiran siswa telah menjadi tujuan banyak sekolah. Jumlah ketidakhadiran siswa dapat menjadi estimasi siswa akan gagal sekolah atau drop out, karena siswa yang jarang hadir di sekolah memiliki kesempatan yang lebih sedikit untuk mempelajari materi yang memampukan mereka untuk sukses di sekolah[1][2][3]. Oleh karena itu, jumlah ketidakhadiran yang besar dapat menghasilkan dampak negatif bagi siswa dan juga bagi sekolah.

Pada Sekolah Menengah Kejuruan Negeri-4 (SMKN-4) Palangka Raya, absensi adalah salah satu perangkat yang digunakan oleh SMKN-4 Palangka Raya untuk mencapai Visi sekolah, yaitu menyiapkan Sumber Daya Manusia yang memiliki Intaq, Iptek dan Seni untuk mengisi pembangunan Bangsa dalam era globalisasi. Dengan absensi, pihak sekolah dapat memonitor dan mengevaluasi ketidakhadiran dan kehadiran siswa. Tingkat kehadiran siswa yang stabil dan tepat waktu adalah salah satu tolak ukur untuk menghasilkan lulusan SMKN-4 yang aktif dan produktif. Saat ini proses pengambilan data absensi di SMKN-4 dilakukan dengan cara konvensional di atas kertas. Sistem absensi 
yang telah lama digunakan oleh SMKN-4 dapat ditingkat performanya, sehingga dapat meningkatkan pelayanan terhadap siswa dan membantu sekolah mengolah data kehadiran siswa.

Perangkat handphone Android yang dimiliki oleh guru-guru wali kelas dapat dimanfaatkan untuk meningkatkan performa sistem pencatatan absensi di SMKN-4. Penelitian ini bertujuan untuk merancang dan membangun aplikasi absensi pada platform Android[4]-[6] untuk memfasilitasi proses absensi di SMKN-4 Palangka Raya. Sistem absensi siswa dapat dibangun sebagai sebuah aplikasi yang dapat berfungsi optimal untuk mengelola data ketidakhadiran maupun kehadiran siswa setiap harinya. Penelitian ini memilih platform Android untuk membangun aplikasi absensi karena Android merupakan sebuah sistem operasi yang bersifat open platform[7][8][9][10], sehingga tidak merujuk pada suatu perusahaan atau suatu provider. Sifat open platform Android, memungkinkan pengembangan, akses, dan modifikasi terhadap aplikasi dapat dilakukan secara bebas sesuai dengan kebutuhan. Alasan lainnya dikarenakan perangkat handphone Android mudah diperoleh dengan harga yang murah, dan banyak guru wali kelas di SMKN-4 telah menggunakan handphone dengan sistem operasi Android. Sehingga proses implementasi teknologi aplikasi absensi di SMKN-4 Palangka Raya bisa lebih efektif.

\section{METODOLOGI PENELITIAN}

Pengembangan Aplikasi Absensi pada penelitian ini melalui beberapa tahapanWaterfall[11], yaitu.

\section{A. Requirement Analysis and Definition}

Tahap ini adalah tahap menganalisa kebutuhan yang diperlukan dalam pembuatan aplikasi absensi untuk SMKN-4 Palangka Raya. Pada tahap ini dianalisa fitur-fitur yang perlu dibangun di dalam Aplikasi Absensi. Pada tahapan ini dihasilkan flowchart sistem baru untuk Aplikasi Absensi, seperti ditunjukkan oleh Gambar 1 dan Gambar 2.

Gambar 1 menunjukkan alur proses sistem untuk menginputkan data absensi setiap harinya. Tahapan penginputan data absensi siswa pada gambar 1 adalah seperti berikut.

1. User mengakses Aplikasi Absensi

2. User melakukan proses input user name dan password untuk dapat masuk ke aplikasi, jika input sesuai maka proses sistem berlanjut dan apabila tidak sesuai, maka sistem akan meminta untuk mengulang input.

3. User melakukan proses input data absensi siswa.

Pada aplikasi absensi ini, user adalah Guru Wali Kelas dan Ketua Kelas. Sesuai dengan kebutuhan proses bisnis di SMKN-4, Ketua Kelas diberikan akses pada Aplikasi Absensi untuk membantu Guru Wali Kelas.

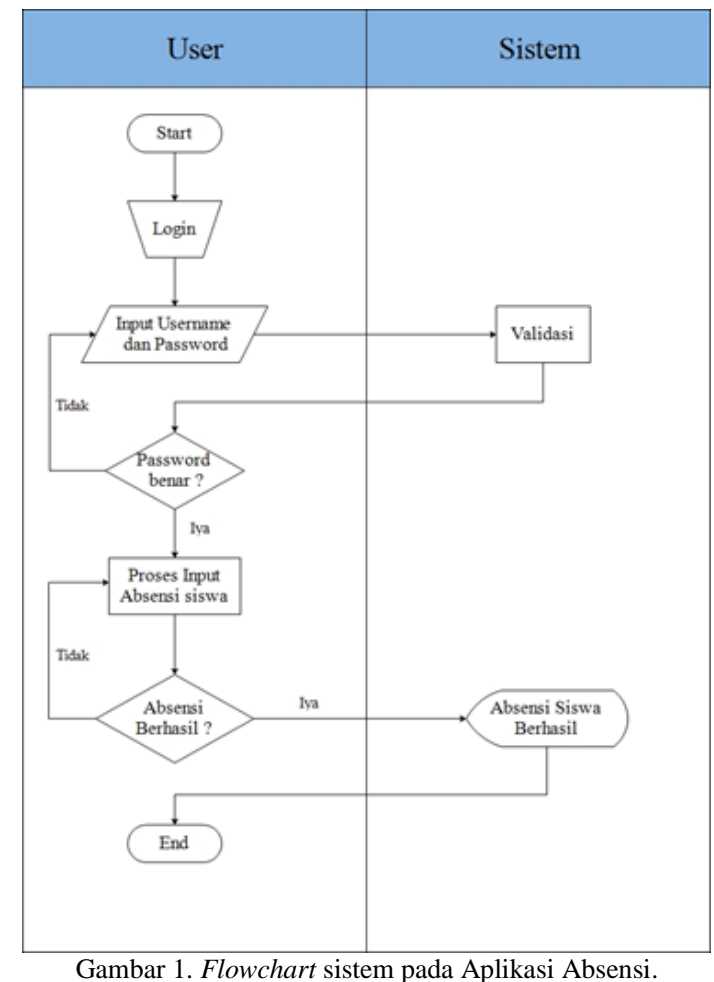




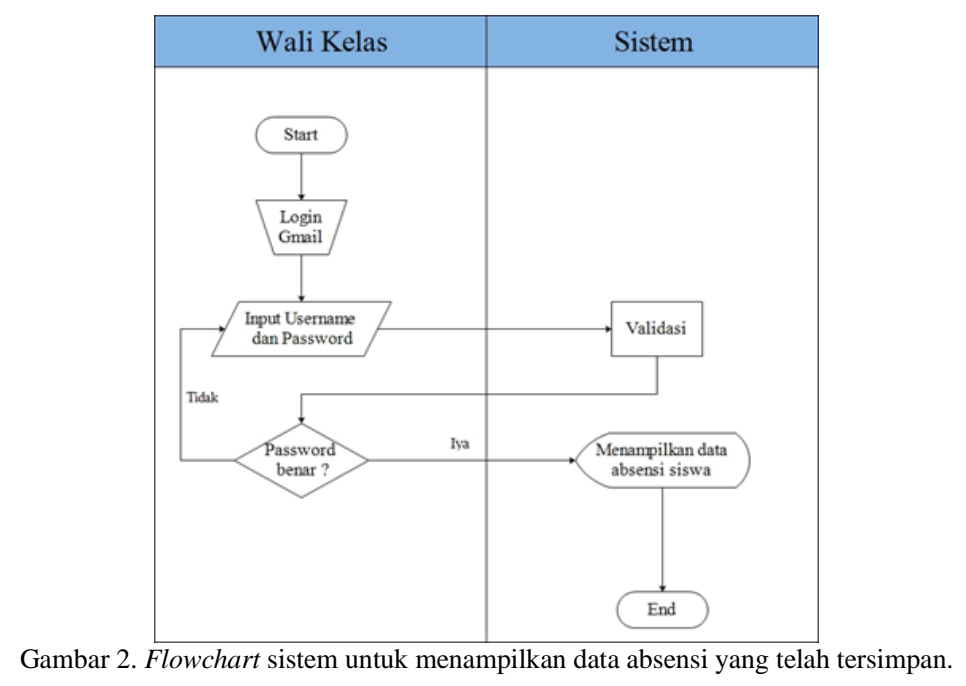

Gambar 2 menunjukan alur proses sistem untuk menampilkan rekapitulasi data absensi siswa yang disimpan oleh Aplikasi Absensi pada Google Drive pada akun Google milik Guru Wali kelas. Tahapan untuk mengakses rekapitulasi kehadiran siswa adalah seperti berikut:

1. Wali Kelas mengakses Gmail driver.

2. Wali Kelas menginput keyword berupa username dan password Gmail untuk melihat kehadiran siswa berupa data google excel yang ada di google driver yang akan menampilkan data kehadiran siswa.

\section{B. System and Software Design}

Pada tahapan ini dilakukan proses desain untuk Aplikasi Absensi yang meliputi desain sistem dan desain interface aplikasi. Tahapan ini menghasilkan beberapa diagram Unified Modelling Language (UML) seperti diagram use case, activity, dan class [12]. Kemudian pada tahapan ini juga dihasilkan desain interface dalam bentuk stroyboard.

1. Use Case Diagram, mempresentasikan interaksi antara user dengan sistem pada Aplikasi Absensi. Gambar 3. Menunjukkan user dalam aplikasi absensi ini adalah Ketua Kelas dan Guru Wali Kelas, pada Gambar 3 interaksi antara user pada sistem aplikasi ini terjadi dalam proses login, absensi, lihat kehadiran siswa dan logout.

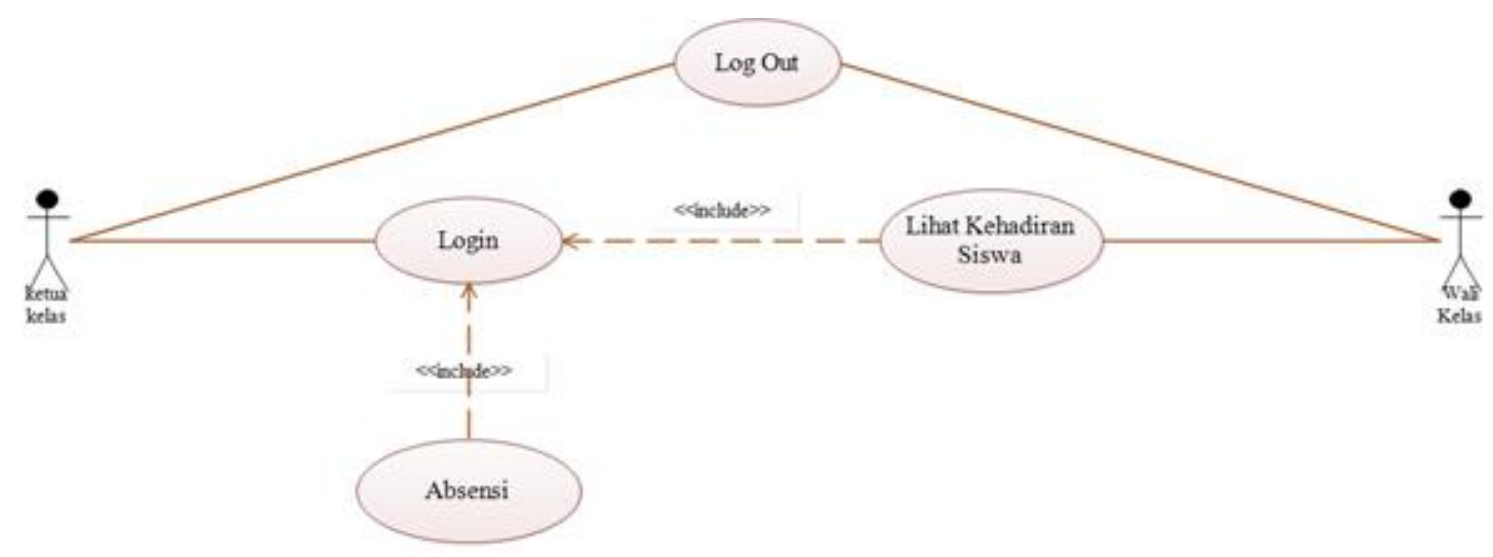

Gambar 3. Use Case Diagram sistem pada Aplikasi Absensi. 


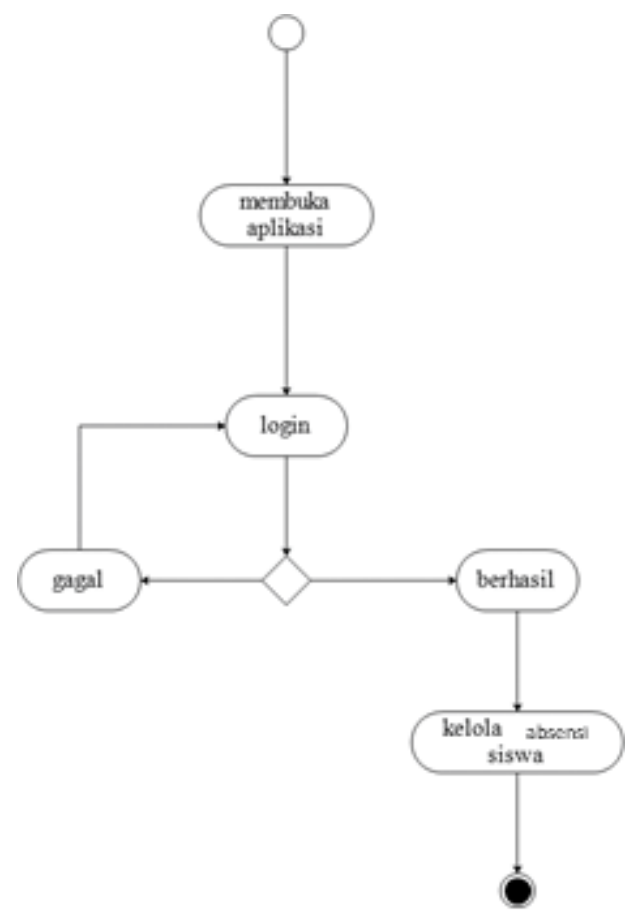

Gambar 4. Activity Diagram pengisian data absensi bagi user Ketua Kelas atau Guru Wali Kelas.

2. Activity Diagram, menggambarkan alir kegiatan di dalam sistem Aplikasi Absensi. Gambar 4 menunjukan activity diagram bagi user Ketua Kelas atau Guru Wali Kelas saat melakukan pengisian data absensi, aliran aktifitas dimulai saat membuka aplikasi, mengisi absensi hingga Logout dari sistem. Gambar 5 menunjukkan activity diagram bagi user Guru Wali Kelas saat melihat data absensi siswa, aliran aktifitas dimulai dari akun di Gmail, menampilkan data absensi yang tersimpan di google drive hingga keluar dari sistem.

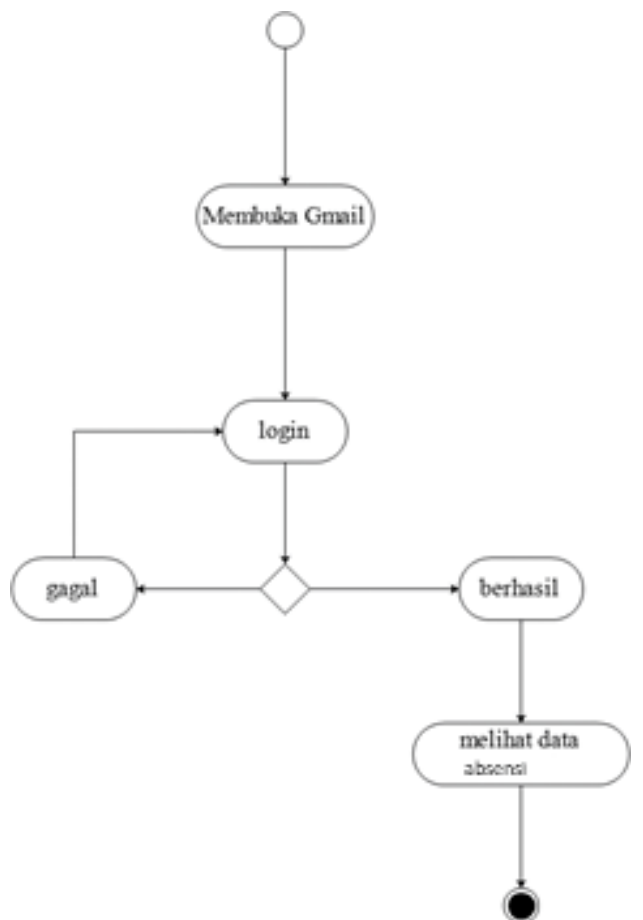

Gambar 5. Activity Diagram melihat data absensi yang telah tersimpan bagi user Guru Wali Kelas. 


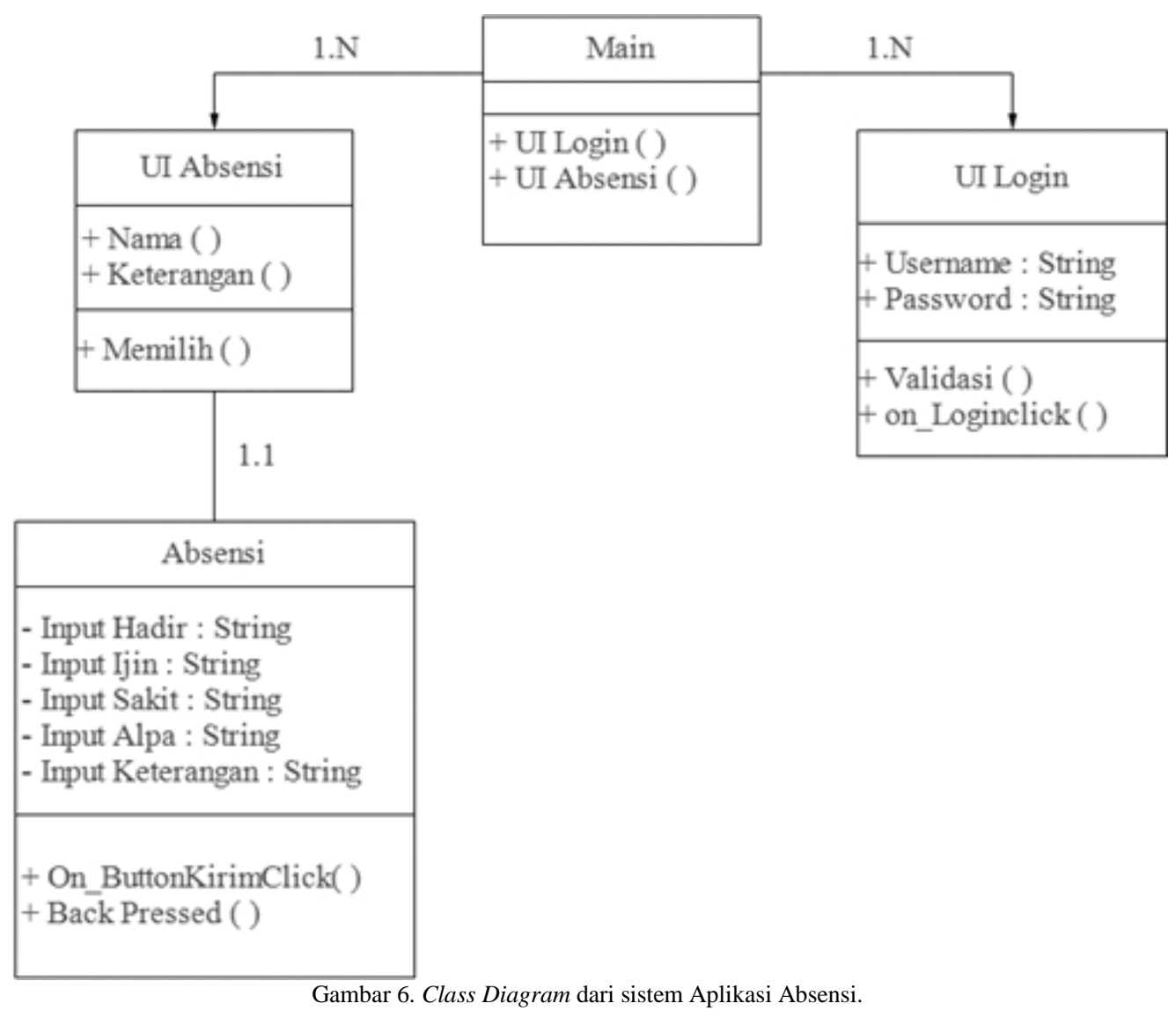

3. Class Diagram, menggambarkan struktur dan deskripsi class, package dan objek beserta hubungan objek-objek di dalam sistem Aplikasi Absensi. Gambar 6 menunjukkan class diagram Aplikasi Absensi.

4. Storyboard, merupakan gambaran dari Aplikasi Absensi. Storyboard dibuat berdasarkan kebutuhan yang diusulkan oleh SMKN-4 Palangkaraya sebagai rekomendasi untuk penyempurnaan tampilan dalam menangani interaksi antara user dan sistem pada Aplikasi Absensi. Gambar 7 menunjukan scene form Login, terdapat button log in untuk melanjutkan absensi setelah memasukan username dan password. Saat button login di-click maka listview widget akan menampilkan daftar nama siswa di kelas tersebut, seperti ditunjukkan pada Gambar 8. Scene form absensi pada Gambar 8 berisi daftar nama siswa dengan pilihan keterangan Hadir, Ijin, Sakit, Alpa. Pada scene form absensi, Ketua Kelas atau Guru Wali Kelas dapat melakukan pendataan kehadiran siswa. Kemudian data kehadiran siswa akan tersimpan secara otomatis di dalam akun Google Drive milik Guru Wali Kelas.

\section{Implementation and Unit Testing}

Pada tahapan implementation and unit testing dilakukan proses pembuatan Aplikasi Absensi yaitu proses pengkodean hingga menghasilkan satu set program atau unit program. Tahap ini merupakan implementasi dari tahap desain.

\section{Integration and System Testing}

Pada tahapan integration and system testing, setiap fitur dalam Aplikasi Absensi diintegrasikan dan diuji sebagai satu sistem yang utuh untuk memastikan sistem sudah memenuhi persyaratan yang ada. Setelah itu sistem akan dikirim kepada pengguna sistem yaitu pihak sekolah. Testing yang digunakan di dalam penelitian ini adalah blackbox testing[13].

\section{E. Operation and Maintenance}

Pada tahapan operation and maintenance, aplikasi absensi siap untuk instalasi dan mulai digunakan sebagai mana fungsinya. Pada tahap ini juga dilakukan perbaikan terhadap kesalahan yang tidak 
ditemukan pada proses pengkodean sebelumnya menjadi sebuah program yang utuh. Dalam tahap ini juga dilakukan pengembangan sistem seperti penambahan fitur atau fungsi baru yang telah disesuaikan dengan kebutuhan dari sekolah.
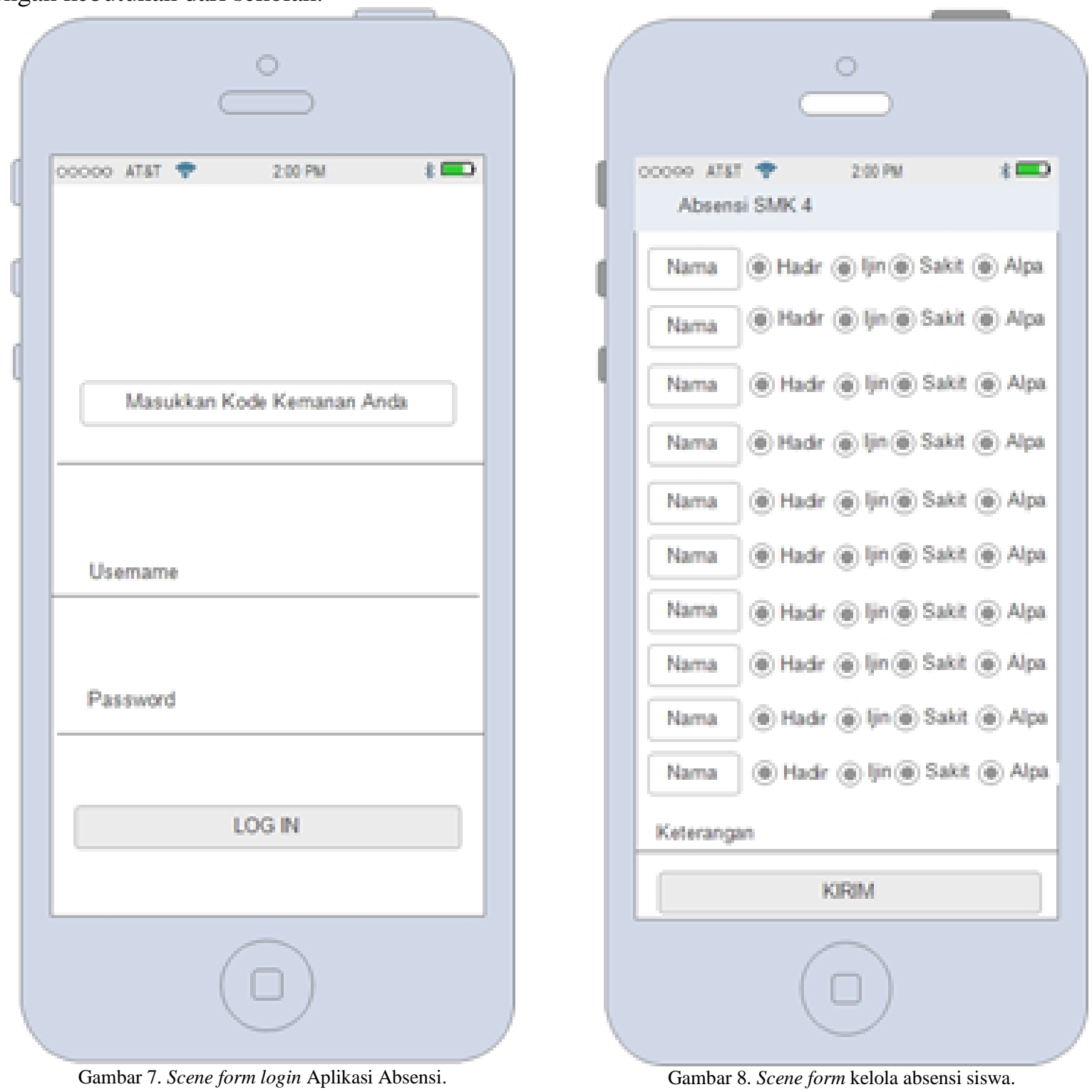

III. HASIL DAN PEMBAHASAN

\section{A. Hasil Implementasi}

Hasil dari penelitian ini adalah Aplikasi Absensi pada platform Android. Komponen pendukung pada aplikasi ini adalah Google Sheet sebagai media penyimpanan koleksi data absensi siswa. Gambar 9 adalah interface form absensi yang akan ditampilkan setelah user sukses melakukan login. Untuk melakukan pendataan kehadiran siswa, user dapat memilih dan klik option button pada keterangan (Hadir, Ijin, Sakit atau Alpa) yang ada disamping nama siswa.

Setelah user Ketua Kelas atau Guru Wali Kelas selesai melakukan absensi dan menekan tombol kirim dan data berhasil dikirimkan maka, aplikasi akan langsung mengirim data absensi ke google sheet dari akun google Guru Wali Kelas. Tampilan data absensi dari google sheet dapat dilihat pada Gambar 10. 


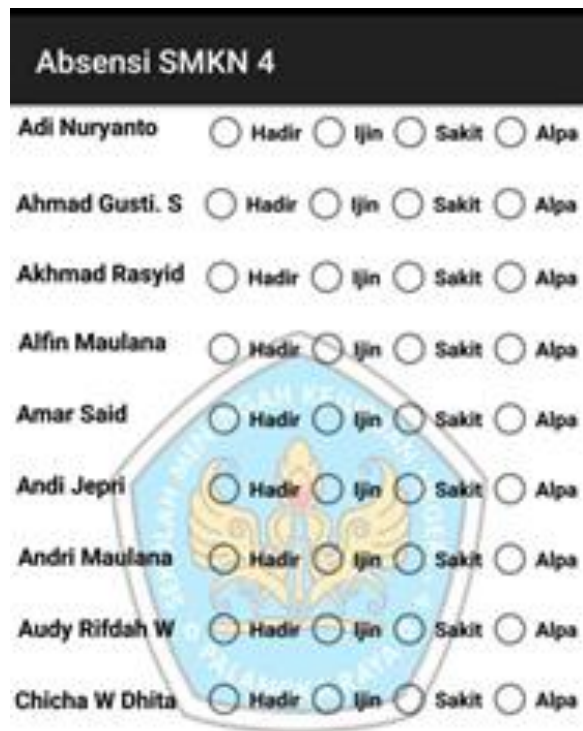

Keterangan

tocinsuxes:

KIRIM

Gambar 9. Interface form kelola absensi.

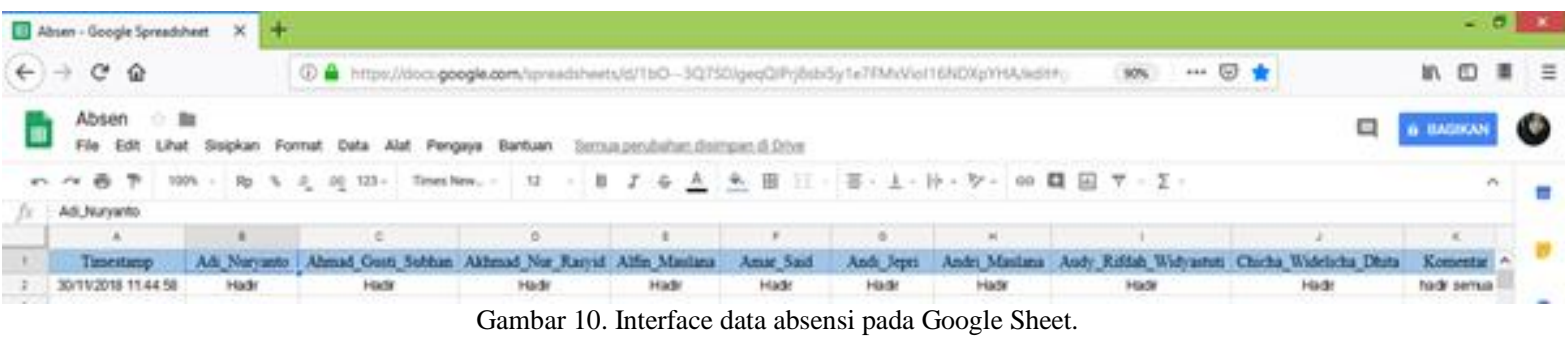

TABEL I.

PENGUJIAN PADA FORM LOGIN

\begin{tabular}{|c|c|c|c|c|}
\hline No. & Test Case & Kondisi Pengujian & Hasil Keluaran & Hasil Tes \\
\hline \multirow[t]{3}{*}{1.} & $\begin{array}{l}\text { Login dengan hak } \\
\text { akses Ketua kelas. }\end{array}$ & $\begin{array}{l}\text { - Ketua kelas memasukkan username } \\
\text { benar dan password salah. }\end{array}$ & - $\begin{array}{l}\text { Peringatan Login tidak } \\
\text { sesuai }\end{array}$ & OK \\
\hline & & $\begin{array}{l}\text { - Ketuakelas memasukkan username salah } \\
\text { dan password yang salah }\end{array}$ & $\begin{array}{l}\text { - Peringatan Login tidak } \\
\text { sesuai. }\end{array}$ & OK \\
\hline & & $\begin{array}{l}\text { - } \quad \text { Ketuakelas memasukkan } \\
\text { - } \quad \text { username benar dan password benar }\end{array}$ & $\begin{array}{l}\text { Peringatan login sukses } \\
\text { dan Ketua kelas masuk ke } \\
\text { halaman absensi }\end{array}$ & OK \\
\hline
\end{tabular}

TABEL II.

PENGUJIAN PADA FORM ABSENSI

\begin{tabular}{|c|c|c|c|c|c|c|c|}
\hline No. & Test & ase & & Kondisi Pengujian & & Hasil Keluaran & Hasil Tes \\
\hline 1. & $\begin{array}{l}\text { Klik } \\
\text { Absensi }\end{array}$ & Menu & - & $\begin{array}{l}\text { Tampilkan untuk mengisi Absensi } \\
\text { para siswa di dalam kelas. }\end{array}$ & - & $\begin{array}{l}\text { Menampilkan Radio } \\
\text { Button dalam kondisi } \\
\text { dipilih. }\end{array}$ & $\mathrm{OK}$ \\
\hline 2. & $\begin{array}{l}\text { Klik } \\
\text { Kirim }\end{array}$ & menu & - & $\begin{array}{l}\text { Mengirim data Absensi dengan cara } \\
\text { mengklik tombol kirim. }\end{array}$ & - & $\begin{array}{l}\text { Pemberitahuan proses } \\
\text { pengiriman data absensi } \\
\text { berhasil dan ditampilkan } \\
\text { pada halaman absensi. }\end{array}$ & OK \\
\hline
\end{tabular}




\section{B. Pengujian}

Pengujian sistem dilakukan dengan melakukan blackbox testing untuk membuktikan bahwa Aplikasi Absensi dapat berfungsi sesuai tujuannya. Hasil pengujian dapat dilihat pada Tabel 1 dan Tabel 2 . Pengujian yang telah dilakukan pada fungsi log in, fungsi input data absensi siswa dan proses penyimpanan atau pengiriman data ke google drive menunjukkan kinerja aplikasi yang baik, karena dapat memberikan hasil keluaran seperti yang diharapkan.

\section{Pembahasan}

Memiliki sistem yang baik untuk mengelola data kehadiran siswa adalah tujuan dari semua sekolah untuk meningkatkan mutu pendidikan dan memberi pelayanan terbaik bagi siswa, guru, orang tua dan semua pihak yang berkepentingan. Oleh karena itu beberapa penelitian telah dilakukan untuk memenuhi kebutuhan sekolah dalam pengelolaan data dan informasi terkait kehadiran siswa dalam kegiatan belajar di sekolah.

Hudayati dan Sutama [14] telah membangun sebuah sistem informasi manajemen absensi bagi siswa di SMP Negeri 14 Surakarta. Sistem yang dibangun oleh Hudayati dan Sutama, berisi fungsi untuk input data siswa dan orang tua siswa, fungsi untuk mengelola data kehadiran siswa dan dilengkapi dengan fasilitas short message service (SMS) untuk mengirimkan laporan kehadiran siswa kepada orang tua. Sistem menggunakan modem SMS dan membutuhkan pulsa untuk mengirimkan SMS kepada orang tua, sehingga pihak sekolah perlu mengalokasikan sejumlah dana untuk mengimplementasikan sistem tersebut.

Penelitian berikutnya oleh Cahyono [15] adalah sebuah sistem absensi berbasis web pada SMK YPKK 1 Sleman Yogyakarta. Cahyono telah membangun sistem absensi dengan banyak fungsi untuk memenuhi kebutuhan sekolah yang menjadi obyek penelitiannya, walaupun masih ada beberapa fungsi yang perlu ditambahkan lagi untuk meningkatkan kontribusi sistem bagi pihak sekolah.

Penelitian yang dilakukan oleh [14], [15] menghasilkan sistem dengan banyak fungsionalitas untuk memenuhi kebutuhan pihak sekolah. Sistem yang dikembangkan oleh [14], [15] membutuhkan sumber daya yang besar untuk mendukung teknologi yang digunakan. Kebutuhan pengembangan sistem ini perlu mendapat perhatian khusus dari pihak sekolah agar Sistem yang dibangun bisa diimplementasikan dengan optimal.

Aplikasi Absensi yang dibangun pada penelitian ini lebih praktis untuk diimplementasikan bila dibandingkan dengan sistem yang dibangun oleh [14], [15]. Sistem pada penelitian ini dibangun pada open platform Android yang telah digunakan pada perangkat handphone guru-guru sekolah, kemudian data-data kehadiran siswa dikelola pada google sheet yang akunnya juga telah dimiliki oleh guru wali kelas.

Namun mengingat kebutuhan yang besar dan beragam akan informasi terkait kehadiran siswa, fungsionalitas pada Aplikasi Absensi ini perlu dikembangkan lagi sesuai dengan kebutuhan siswa, guru, orang tua, sekolah dan juga pihak-pihak yang berkepentingan.

\section{KESIMPULAN}

Aplikasi Absensi ini dibangun dengan metode pengembangan perangkat lunak Waterfall. Data absensi yang diinputkan pada aplikasi disimpan oleh sistem pada Google Sheet. Hasil pengujian terhadap fitur-fitur di dalam aplikasi menunjukkan Aplikasi Absensi dapat berfungsi sesuai tujuannya.

Saran bagi penelitian selanjutnya adalah meningkatkan teknik pengelolaan rekaman data absensi. Pengelolaan data absensi dapat dibuat pada suatu sistem basis data, agar data absensi dapat diolah lebih optimal lagi untuk memenuhi kebutuhan pihak sekolah.

\section{DAFTAR PUSTAKA}

[1] J. L. Epstein and S. B. Sheldon, "Present and accounted for: Improving student attendance through family and community involvement," J. Educ. Res., vol. 95, no. 5, pp. 308-318, 2002.

[2] S. B. Sheldon and J. L. Epstein, "Improving student behavior and school discipline with family and community involvement," Educ. Urban Soc., vol. 35, no. 1, pp. 4-26, 2002.

[3] S. B. Sheldon and J. L. Epstein, "Getting Students to School: Using Family and Community Involvement to Reduce Chronic Absenteeism," Sch. COMMUNITY J., pp. 39-56, 2004.

[4] A. A. Huda, 24 jam !! pintar pemprograman android. Yogyakarta: C.V ANDI OFFSET, 2012.

[5] N. S. H, Pemrograman Aplikasi Mobile Smartphone Dan Tablet PC Berbasis Android. Bandung: Informatika, 2015.

[6] J. E. Istiyanto, Pemprograman smartphone mengunakan Sdk android dan hacking android. Yogyakarta: Graha Ilmu, 2013. 
[7] N. Gandhewar and R. Sheikh, "Google Android : An Emerging Software Platform For Mobile Devices," Int. J. Comput. Sci. Eng., vol. Supplement, no. May, pp. 12-18, 2011.

[8] R. Rogers, J. Lombardo, Z. Mednieks, and B. Meike, Programming with the google SDK, 1st ed. O'Reilly Media, Inc., 2009.

[9] K. Sharma, "Android: the Possibilities Are Endless," Int. J. Adv. Res. Comput. Sci., vol. 50, no. 22, p. ifc, 2010.

[10] L. Gu, J. Wang, and L. Ma, "Research and Development for Android Platform," Int. J. Multimed. Ubiquitous Eng., vol. 9, no. 4, pp. 187198, 2014.

[11] I. Sommerville, Software Engineering, 9th Editio. America: Pearson Education ,Inc, 2011.

[12] dan S. M. Rosa. A.S., Rekayasa Perangkat Lunak, 2nd ed. Bandung: Informatika, 2014.

[13] R. S. Pressman, Software Engineering: a practitioner's approach, 7th ed. New York: McGraw-Hill, 2010.

[14] N. Hudayati and Sutama, "PENGEMBANGAN SISTEM INFORMASI MANAJEMEN ABSENSI SISWA BERBASIS SMS DI SMP NEGERI 14 SURAKARTA," 2015.

[15] L. Cahyono, "DEVELOPMENT OF WEB-BASED STUDENT ABSENTEEISM INFORMATION SYSTEM IN SMK YPKK 1 SLEMAN YOGYAKARTA,” J. Pendidik. Tek. Inform., 2017. 